\title{
MANAJEMEN PEMBELAJARAN WORK-BASED LEARNING DALAM MENINGKATKAN PRESTASI BELAJAR MAHASISWA PADA MATA KULIAH APPLIED COMPUTER DI POLITEKNIK LP3I BANDUNG
}

\author{
Lulu Ulfa Sholihannisa, S.Pd., M.Pd. \\ Dosen Program Studi Manajemen Informatika \\ Politeknik LP3I Bandung \\ E-Mail : mfha15feb@gmail.com
}

\begin{abstract}
Abstrak : Penelitian ini dilaksanakan dengan tujuan untuk mengetahui fungsi manajemen pembelajaran Work-Based Learning pada mata kuliah Applied Computer di Politeknik LP3I Bandung serta factor pendukung dan penghambat dalam pembelajaran mata kuliah Applied Computer. Penelitian ini merupakan penelitian deskriptif analisis kualitatif. Penelitian ini dilakukan secara langsung dengan melakukan catatan lapangan dan kamera sebagai alat dokumentasi. Pengumpulan data dilakukan dengan menggunakan metode observasi dan wawancara. Instrumen dalam penelitian ini tertuju pada peneliti itu sendiri, karena ia berperan sebagai pengamat penuh dan berperan serta secara lengkap. Hasil dari peneilitian ini adalah manajemen pembelajaran itu sendiri mulai dari perencanaan, pelaksanaan, penilaian pembelajaran, dampak dari manajemen pembelajaran serta faktor pendukung dan penghambat dalam manajemen pembelajaran pada mata kuliah Applied Computer dalam meningkatkan prestasi belajar mahasiswa melalui model pembelajaran Work-Based Learning.
\end{abstract}

Kata kunci : Manajemen pembelajaran, applied computer, WBL

\section{Pendahuluan}

Pendidikan bukan merupakan suatu keharusan bagi setiap warga negara melainkan pendidikan adalah kebutuhan. Dalam jenjang Pendidikan Tinggi setiap warga negara berhak untuk menentukan jenis pendidikan yang akan ditempuh baik itu pendidikan akademik, pendidikan profesi, atau pendidikan vokasi. Menurut Tony Wagner (Widarto, -:2) terdapat beberapa kompetensi dari hasil produk pendidikan yang menjadi pembeda bagi siswa pada abad 21 ini yang harus dimiliki, antara lain: 1) Communication Skills; 2) Critical and Creative Thinking; 3) Information/Digital Literacy; 4) Inquiry/reasoning Skills; 5) Interpersonal Skills; 6) Multicultural/Multilingual Literacy; 7) Problem Solving; dan 8) Technological Skills.

Tujuh dari delapan kompetensi di atas menunjukan pada soft skills atau kemampuan dan bakat yang sudah ada pada individu seseorang, sedangkan technological skill itu sendiri merupakan hard skill atau kemampuan teknis yang perlu dimiliki oleh seseorang pada profesi tertentu, salah satunya berupa kemampuan menguasai teknologi. Oleh sebab itu untuk menunjang kemampuan teknologi yang semakin mutakhir pada abad 21 ini, pada jenjang pendidikan 
vokasi terdapat beberapa mata kuliah yang akan menunjang pada technological skill. Salah satunya mata kuliah Applied Computer.

Mahasiswa yang mengontrak mata kuliah Applied Computer dituntut untuk menguasai beberapa kompetensi dasar untuk aplikasi perkantoran (software), yaitu Office Program seperti Ms. Word, MS. Excel, dan MS. Power Point. Metode pembelajaran Applied Computer dilaksanakan di laboratorium komputer dengan waktu pembelajaran 4 SKS. Mata kuliah ini diberikan pada mahasiswa tingkat pertama. Sesuai dengan nama mata kuliahnya sebagai mata kuliah aplikasi dengan pembelajaran memadukan teori dan praktik langsung, sehingga menuntut kreatifitas dosen dalam mengajar dan juga menuntut mahasiswa untuk lebih aktif dalam belajar dan mengerjakan semua tugas-tugas perkuliahan.

Learning output sebagai prestasi belajar, sangat diharapkan dari setiap mahasiswa dengan nilai yang sangat baik. Menurut Ngalim Purwanto (1978) dalam Habsari (75: 2005) "prestasi belajar adalah hasil-hasil belajar yang telah diberikan guru kepada murid-murid atau dosen kepada mahasiswanya dalam jangka tertentu".

Model pembelajaran WBL ini pada dasar memadukan antara teori dengan praktik dan pengetahuan dengan dunia nyata. Dalam mata kuliah Applied Computer, WBL dapat diterapkan dalam proses pembelajaran karena lebih mengedepankan praktik secara langsung, sehingga setiap mahasiswa dapat mengeksplor semua kemampuan dan pengalaman yang telah dimiliki setiap mahasiswa dari jenjang pendidikan menengah yang telah dilalui pada mata kuliah ini.

\section{Landasan Teori}

\subsection{Manajemen Pembelajaran}

Manajemen dalam dunia pendidikan lebih dikenal dengan istilah pengelolaan atau administrasi. Jika manajemen pendidikan mempunyai arti luas yaitu mencakup pengelolaan sumber daya untuk mencapai tujuan pendidikan secara produktif, maka manajemen pembelajaran merupakan bentuk pengelolaan pembelajaran dalam kegiatan belajar mengejar di dalam kelas.

Manajemen pembelajaran itu sendiri teridiri dari dua kata yaitu kata manajemen dan pembelajaran, dimana keduanya mempunyai arti dan makna yang berbeda. Kata manajemen berasal dari bahasa italia "maneggiare" yang bermakna mengendalikan khususnya mengendalikan kuda. Dalam bahasa latin manage disebut dengan "manus" yang bermakna tangan (hand). Dalam istilah Prancis menggunakan kosakata "management", lalu menjadi "menagement" yang berpengaruh pada pembentukan kosakata Inggris “management" sekitar abad 17 dan 18 (Hoesada, 2013: 51).

Menurut Sumarsan $(2013,2)$ "manajemen diartikan sebagai seni dalam proses perencanaan, pengorganisasian, pengarahan, dan pengendalian penggunaan sumber daya untuk mencapai tujuan/sasaran kerja". Pengertian tersebut diilustrasikan oleh Sumarsan dalam bagan dibawah ini: 


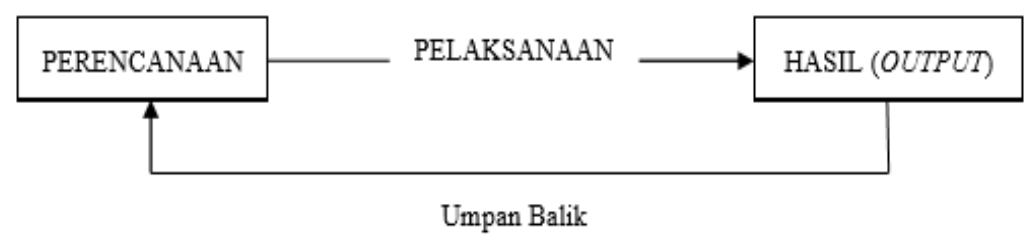

Bagan 1 Skema Umpan Balik Manajemen

Winardi (2004: 4) menjelaskan bahwa manajemen adalah "proses perencanaan, pengorganisasian, pergerakan serta pengawasan terhadap aktivitas-aktivitas suatu organisasi dalam rangka upaya mencapai suatu koordinasi sumber-sumber daya manusia dan sumber-sumber daya alam dalam hal pencapaian sasaran secara efektif serta efisien".

Sedangkan Terry (1977) dalam Herujito (2001:3) menyatakan "Manajemen adalah suatu Proses yang berbeda terdiri dari planning, organizing, actuating, controlling, yang dilakukan untuk mencapai tujuan yang ditentukan dengan menggunakan manusia dan sumber daya lainnya". Pengertian manajemen yang dijelaskan oleh Terry merupakan fungsi-fungsi proses manajemen itu sendiri. Fungsi-fungsi tersebut dapat dilihat pada gambar dibawah ini:

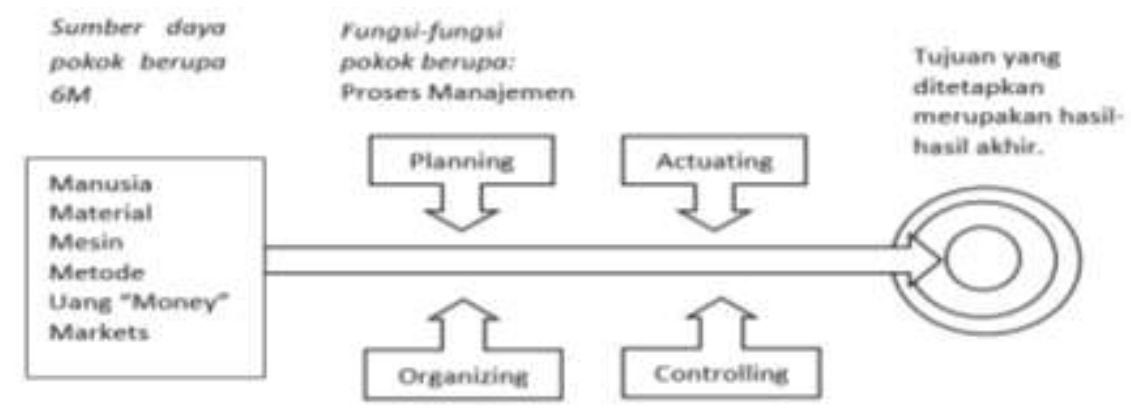

Gambar 1 Fungsi Manajemen Menurut Terry

Dalam dunia pendidikan, manajemen pendidikan yang baik dapat menghasilkan tujuan pendidikan yang bermutu. Agar tujuan pendidikan itu tercapai dengan sempurna, sumber daya juga menjadi alat penunjang pendidikan tersebut. Sumber daya dalam istilah manajemen disebut sebagai sarana manajemen atau dikenal dengan istilah Tools of Management.

Menurut Handoko (2009) "tools tersebut digunakan untuk mencapai suatu tujuan tertentu" (Fachruddin, 2016: 9). Dari gambar diatas dapat dijelaskan sebagai berikut:

1) Man (manusia) merujuk pada sumber daya manusia yang dimiliki oleh organisasi. Dalam manajemen, faktor manusia adalah yang paling menentukan. Sedangkan 
istilah Man dalam dunia pendidikan adalah siswa/mahasiswa, guru/dosen, dan tenaga kependidikan lainnya.

2) Money atau uang merupakan salah satu unsur yang tidak dapat diabaikan. Uang merupakan alat tukar dan alat pengukur nilai. Pada dunia pendidikan money lebih identik dengan masalah dana dan pembiayaan. Sebagai contoh, pembiayaan diperlukan untuk membiayai operasional sekolah seperti kebutuhan perlengkapan siwa, buku-buku pelajaran dan lain-lain. Sedangkan dalam pendidikan tinggi, contoh dana atau pembiayaan adalah pembiayaan pengadaan alat atau media pembelajaran seperti komputer, laptop, infocus, beasiswa mahasiswa berprestasi dan lain sebagainya.

3) Material terdiri dari bahan setengah jadi (raw materi) dan bahan jadi. Bahan atau materi merupakan salah satu sarana yang apabila tidak disertakan materi tersebut tidak akan tercapai tujuan yang dikehendaki. Mengenai sarana dan prasarana pembelajaran di perguruan tinggi tercantum dalam PERMENRISTEKDIKTI No 44 Tahun 2015 tentang Standar Nasional Pendidikan Tinggi (SN Dikti) yaitu: "Standar sarana pembelajaran paling sedikit terdiri atas: a) Perabot; b) Peralatan pendidikan; c) Media pendidikan; d) Buku, buku elektronik, dan repository; e) Sarana teknologi informasi dan komunikasi; f) Instrumentasi eksperimen; g) Sarana olahraga; h) Sarana berkesenian; i) Sarana fasilitas umum; j) Bahan habis pakai; k) Sarana pemeliharaan, keselamatan, dan keamanan. Adapun standar prasarana pembelajaran paling sedikit terdiri atas: a) Lahan; b) Ruang kelas; c) Perpustakaan; d) Laboratorium/studio/bengkel kerja/unit produksi; e) Tempat berolah raga; f) Ruang untuk berkesenian; g) Ruang unit kegiatan mahasiswa; h) Ruang pimpinan perguruan tinggi; i) Ruang dosen; j) Ruang tata usaha; k) Fasilitas umum yang meliputi: jalan, air, listrik, jaringan komunikasi suara dan data".

4) Machine atau mesin digunakan untuk memberi kemudahan atau menghasilkan keuntungan yang lebih besar serta menciptakan efisiensi kerja. Mesin dalam bidang pendidikan adalah teknologi pendidikan itu sendiri.

5) Metode adalah salah satu cara kerja yang memperlancar jalannya pekerjaan manajer. Sebuah metode dinyatakan sebagai penetapan cara pelaksanaan kerja suatu tugas dengan memberikan berbagai pertimbangan-pertimbangan kepada sasaran fasilitasfasilitas yang tersedia dan penggunaan waktu. Namun, sekalipun terdapat metode yang baik, sedangkan orang yang melaksanakannya tidak mengerti atau tidak memiliki pengalaman maka hasilnya tidak akan memuaskan.

6) Market atau pasar adalah tempat di mana organisasi menyebarluaskan (memasarkan) produknya. Dengan demikia market yang dimaksud dalam pendidikan ini adalah masyarakat luas yang berniat menyekolahkan atau menguliahkan anak-anaknya ke sekolah atau ke perguruan tinggi yang dituju.

Pada dunia pendidikan pembelajaran merupakan salah satu proses perubahan tingkah laku. Pada umumnya seseorang dikatakan telah belajar apabila ia mempunyai perubahan dalam 3 aspek, yaitu aspek kognitif, afektif, dan psikomotor. Hal tersebut diungkapkan Gagne yang dikutip oleh Benny (2009: 6) yaitu belajar dapat diartikan sebagai "suatu 
proses alami yang dapat membawa perubahan pada pengetahuan, tindakan, dan perilaku seseorang".

Menurut Hamalik, O (2006: 154) mengungkapkan bahwa "pembelajaran adalah suatu kombinasi yang terdiri dari unsur-unsur manusiawi, fasilitas, perlengkapan, serta prosedur yang saling mempengaruhi untuk mencapai tujuan dari pembelajaran itu sendiri”.

Merujuk pada konsep manajemen dan pembelajaran diatas, manajemen pembelajaran dapar diartikan sebagai suatu proses pembelajaran melalui perencanaan pembelajaran, pengorganisasian pembelajaran, pelaksanaan pembelajaran, dan pengontrolan pembelajaran.

Manajemen pembelajaran menurut Syarifuddin (2005: 18) dijelaskan bahwa mananajemen pembelajaran adalah "aplikasi prinsif, konsep, dan teori manajemen dalam aktivitas pembelajaran untuk mencapai tujuan pembelajaran”.

Adapun pendapat Garina (2015: 2) manajemen pembelajaran adalah "segenap proses usaha bersama untuk memperlancar pencapaian tujuan pengajaran dengan titik berat pada usaha meningkatkan kualitas interaksi belajar-mengajar".

\subsection{Prestasi Belajar}

Seseorang yang belajar selalu berharap untuk mendapatkan hasil yang terbaik secara nilai akademik karena nilai akademik tersebut merupakan wujud prestasi atas kegiatan pembelajaran yang telah diikuti.

Olivia (2011:73) mengungkapkan bahwa "prestasi belajar adalah salah satu hasil pembelajararan yang mampu mencerminkan keberhasilan siswa dari pembelajarannya, dari tujuan belajar yang telah ditetapkan. Hasil belajar siswa dapat meliputi aspek kognitif (pengetahuan), afektif (sikap), dan psikomotori (tingkah laku)".

Sedangkan hasil pembelajaran menurut Degeng (1989) adalah "semua efek yang dapat dijadikan sebagai indicator tentang nilai dari penggunaan strategi pembelajaran di bawah kondisi yang berbeda.

Wena $(2011,6)$ menyebutkan variable hasil pembelajaran diklasifikasikan menjadi tiga yang dapat dilihat pada bagan dibawah ini:

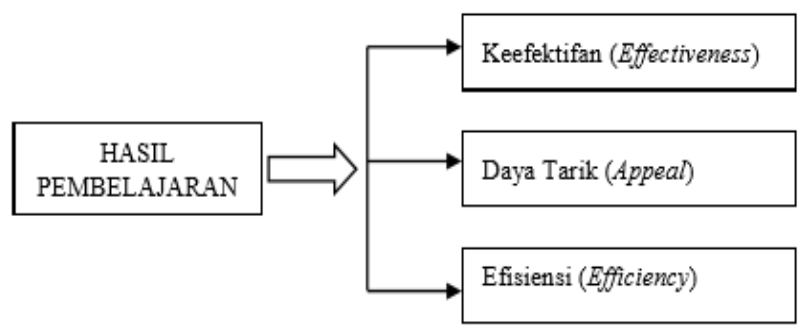

Bagan 2 Variable Hasil Belajar 
1) Keefektifan pembelajaran

Keefektifan pembelajaran dapat diukur dari tingkat pencapaian siswa dan terdapat empat indicator, yaitu a) kecermatan penguasaan perilaku yang dipelajari; b) kecepatan unjuk kerja; c) tingkat alih belajar; dan d) retensi.

2) Efisiensi pembelajaran

Efisiensi pembelajaran diukur dengan antara keefektifan dan jumlah waktu yang dipakai siswa dan/atau jumlah biaya yang digunakan dalam pembelajaran.

3) Daya Tarik

Daya Tarik pembelajaran diukur dengan mengamati kecenderungan siswa untuk tetap atau terus belajar.

Dari pernyataan di atas, dapat disimpulkan bahwa prestasi belajar merupakan hasil baik berupa nilai atau reward yang diperoleh oleh peserta didik dari proses pembelajaran yang sedang atau telah ditempuhnya.

\subsection{Model Pembelajaran Work-Based Learning}

Work-Based Learning merupakan salah satu model pembelajaran yang dapat mempersiapkan para pembelajar dalam dunia kerja. Pengertian WBL menurut Medhat (2008: 8) sebagai "a process for recognising, creating, and applying knowledge through, for, and at work which farms part (credits) or all of higher education qualification".

David Boud (2001: 4) mendeskripsikan bahwa program-program WBL secara tipikal memiliki karakteristik: 1) hubungan natara mitra/DUDI dengan institusi pendidikan ditetapkan dengan kontrak secara khusus untuk membangun dan membantu pembelajaran; 2) pembelajar dilibatkan sebagai pekerja (dengan membuat perencanaan belajar yang dinegosiasikan); 3) program pembelajaran dirumuskan dari kebutuhan tempat kerja dan peserta, dan tidak hanya dari kurikulum akademik yang telah disusun; 4) program pembelajaran dilakukan dengan mengadaptasikan bagi pembelajar itu sendiri dan menyesuaikan pada pengalaman pendidikan kerja serta latihan mereka sebelumnya; 5) program pembelajaran sebagai proyek/tugas-tugas yang terintegrasi di tempat tugas; dan 6) ukuran pembelajaran diukur oleh institusi pendidikan, namun pembelajaran dalam WBL tidak ada silabus khusus atau inti materi. Dalam WBL hanya mungkin disiapkan modul untuk memperkenalkan pada situasi kerja yang suatu perusahaan atau tempat kerja.

Peran dosen dalam pembelajaran dengan model pembelajaran WBL adalah untuk: 1) membantu peserta didik agar dapat berpartisipasi dalam mengidentifikasi kebutuhan dan aspirasi mereka dan mengelola proses pembelajaran; 2) bertindak sebagai konsultan proses; 3) membantu peserta didik mengembangkan kemampuan mereka refleksi kritis dan penyelidikan; 4) membantu peserta didik mengidentifikasi dan bekerja dengan isuisu etis; 5) membantu peserta didik membuat penggunaan efektif sumber daya kerja; 6) mengembangkan keterampilan akademik peserta didik dan membantu mereka 
menggunakannya di tempat kerja; 7) Menyediakan keahlian spesialis; dan 8) Menginspirasi dan memotivasi peserta didik (Mujiati et al, 2013: 393).

Model pembelajaran WBL mempunyai manfaat bagi peserta didik dan juga bagi institusi atau lembaga penyelenggara pendidikan. Guide (2000) yang dikutip oleh Siswanto (2011, 41) menjelaskan mengenai manfaat WBL, antara lain:

1) Manfaat bagi peserta didik

a. Meningkatkan motivasi.

b. Mengembangkan tanggung jawab dan kematangan dengan penguatan sumber daya manusia, keterampilan menyelesaikan masalah, kepercayaan diri, dan disiplin diri.

c. Memberikan kesempatan untuk memberikan pilihan okupasi dalam pembuatan pendidikan dan pelatihan jangka panjang atau masa yang akan datang.

d. Menawarkan perencanaan organisasi pelatihan dalam pekerjaan dan kondisi bisnis aktual.

e. Mengembangkan keterampilan human relation melalui interaksi personal dalam setting pekerjaan.

f. Menyediakan keterampilan professional untuk membantu pembelajar membuat transisi dari sekolah ke bekerja.

g. Meningkatkan kepedulian tanggung jawab social dan kemasyarakatan.

h. Meningkatkan kemungkinan mendapatkan pekerjaan dan keahlian.

i. Menambah sumber finansial.

j. Mengurangi resiko siswa tinggal kelas.

k. Memberikan pendidikan teknis yang lebih dibanding yang diberikan disekolah.

1. Membuat instruktur akademik lebih relevan dan aplikatif dalam pekerjaan.

2) Manfaat bagi institusi/lembaga pendidikan

a. Meningkatkan hubungan dan jaringan kerja dengan dunia usaha/industry.

b. Mengembangkan kemitraan diantara sekolah dan komunitas.

c. Membuat kurikulum yang relevan dengan memperluas Pengalaman di kelas dengan diintegrasikan antara teori dan praktik.

d. Dosen memperoleh informasi yang lebih baik dan peduli terhadap kecenderungan mutakhir dari dunia usaha/industry.

e. Membangun relasi public yang positif, sehingga reputasi sekolah meningkat dan menarik para siswa baru.

f. Meningkatkan kualitas lulusan.

g. Menyediakan fasilitas pelatihan dunia usaha/industry yang umumnya sulit untuk disediakan secara finansial oleh sekolah

h. Menciptakan fleksibilatas dan kebutuhan individu siswa dengan tujuan.

\section{Metode Penelitian}

a. Pendekatan Penelitian

Pendekatan pada penelitian ini menggunakan pendekatan kualitatif. Penelitian kualitatif merupakan metode-metode untuk mengeksplorasi dan memahami makna 
yang oleh sejumlah individu atau sekelompok orang dianggap berasal dari masalah sosial atau kemanusiaan (Creswell, 2013: 4).

Pada penelitian ini, penulis bermaksud untuk memperoleh gambaran mengenai manajemen pembelajaran Work-Based Learning pada mata kuliah Applied Computer dalam meningkatkan prestasi belajar mahasiswa.

b. Metode Penelitian

Penggunaan metode dekskriptif pada penelitian ini bermaksud untuk mengungkapkan kenyataan yang ada dilapangan serta dapat dipahami secara mendalam, sehingga dapat memperoleh temuan akhir dari penelitian ini dengan baik.

c. Teknik Pengumpulan Data

Dalam penelitian kualitatif, data bersifat naratif daripada mengedepankan data yang bersifat angka-angka, tetapi dalam penelitian kualitatif pun tidak mengolah data kuantitatif. Hasil analisis dari penelitian kualitatif berupa uraian-uraian deskriptif dan berdasarkan pada analisis data secara induktif. Oleh sebab itu teknik pengumpulan data yang dilakukan oleh penliti adalah observasi, wawancara, dan studi dokumentasi.

Peneliti dapat mengembangkan suatu perspektif dengan pengamatan langsung secara menyeluruh mengenai pemahaman suatu konteks yang sedang diteliti. Dalam observasi penelitian ini, peneliti harus terlebih dahulu mengidentifikasi tempat yang akan dijadikan penelitian sehingga peneliti dapat memperoleh bahan dan materi awal yang berhubungan dengan substansi yang akan diteliti.

Dalam penelitian ini, peneliti melakukan teknik wawancara semi berstruktur sebagai salah satu teknik pengumpulan data. Hal ini berdasarkan pada metode dan instrumen penelitian yang dipakai oleh peneliti dimana data sangat bergantung pada pemahaman peneliti bukan berdasarkan pertanyaan-pertanyaan dalam angket dalam menemukan data.

Selain itu juga studi dokumentasi sangat dibutuhkan dalam penelitian ini. Berbagai dokumen tertulis, foto dan gambar-gambar, catatan lapangan, buku, internet, dan bentuk dokumen lainnya yang menjadi penunjang pengumpulan data pada penelitian ini.

d. Instrument Penelitian

Peneliti sebagai human instrumen, berfungsi menetapkan fokus penelitian, memilih informan sebagai sumber data, analisis data, menafsirkan data dan membuat kesimpulan dari temuan dilapangan.

e. Teknik Analisis Data

Tahapan analisis data selama proses penelitian dilapangan bersamaan dengan pengumpulan data adalah sebagai berikut:

1) Reduksi data. Reduksi data dimaksudkan untuk merangkum, memilah atau memilih hal-hal yang pokok dalam penelitian, memfokuskan hal-hal yang penting. Dengan kata lain, meruduksi data berarti memilih atau memilah data dengan cara menghilangkan atau mengurangi data yang tidak sesuai dengan tujuan penelitian. Oleh sebab itu, dalam penelitian ini, peneliti mencari pokok-pokok temuan 
berkaitan dengan manajemen pembelajaran Work-Based Learning dalam meingkatkan prestasi belajar mahasiswa pada mata kuliah Applied Computer di Politeknik LP3I Bandung.

2) Menyajikan Data (Data Display). Menyajikan data merupakan kegiatan setelah mereduksi data. Menyajikan data dimaksudkan untuk mendeskripsikan sekumpulan informasi atau data sesuai dengan hasil observasi, wawancara, dan dokumentasi. Penyajiannya dapat dilakukan dengan uraian singkat, tabulasi, bagan, hubungan, foto kegiatan dan lain-lain.

3) Penarikan dan Pengujian Kesimpulan (Drawing and Verifying Conclution). Pada dasarnya, peneliti kualitatif mempunyai hambatan dalam menganilis data, yaitu belum adanya prosedur baku yang dijadikan pedoman dalam menganilisis data. Oleh sebab itu kesimpulan yang dibuat oleh peneliti dapat menjadi kesimpulan yang valid dan kredibel, apabila kesimpulan tersebut didukung oleh bukti-bukti yang valid.

f. Uji Keabsahan Data

Untuk menguji keabsahan data pada penelitian ini dilakukan uji kreidibitas data dengan melakukan teknik member check, triangulasi, dan audibilitas data.

Pada tahap member check, pengecekan anggota dilakukan dengan cara menunjukan data atau informasi, termasuk interpretasi peneliti yang disusun dalam format catatan lapangan. Selain itu juga peneliti menyusun suatu laporan penelitian yang diperoleh dari data hasil eksplorasi dalam proses pembelajaran di kelas yang berkaitan dengan manajemen pembelajaran Work-Based Learning untuk meningkatkan prestasi belajar mahasiswa pada mata kulaih Applied Computer di Politeknik LP3I Bandung.

Bentuk triangulasi yang peneliti gunakan dalam penelitian ini adalah triangulasi sumber data. Yaitu, membadingkan data yang diperoleh dari teknik pengumpulan data yang berbeda dalam hal penelitian kualitatif seperti membadingkan data hasil dari pengamatan dari hasil wawancara. Oleh sebab itu, pertanyaan yang peneliti ajukan kepada dosen pengampu mata kuliah, juga peneliti kembali ajukan kepada Ketua Prodi selaku koordinator mata kuliah.

Sedangkan pengecekan audibiltas data ini peneliti lakukan sebagai bahan untuk mengaudit dan melakukan konsultasi atau mendiskusikan mengenai penelitian yang peneliti lakukan. Adapun auditor dalam penelitian ini sebagai pakar ahli dalam bidang manajemen pendidikan adalah dosen pembimbing peneliti.

\section{Hasil dan Pembahasan}

4.1.Perencaan Pembelajaran Mata Kuliah Applied Computer dengan Model Pembelajaran Work-Based Learning dalam Meningkatkan Prestasi Belajar Mahasiswa

Proses perencanaan diawali dengan membuat jadwal mata kulaih Applied Computer yang mengacu pada kurikulum yang berlaku serta kalender akademik dan menentukan dosen pengampu mata kuliah Applied Computer. Dalam melakukan perencanaan pembelajaran ini, Kaprodi memberikan pengarahan kepada dosen koordinator sebagai 
dosen penanggung jawab mata kuliah dalam rapat Prodi mengenai RPS dan instrumen penilaian serta melakukan pengembangan mata kuliah serta menentukan target-target yang harus diperoleh dalam pembelajaran.

Adapun bentuk perencanaan tersebut adalah: 1) Merumuskan tujan pembelajaran dengan capaian hasil sesuai dengan kurikulum yang digunakan (up to date) serta disesuaikan pada standar KKNI, SKKNI dan pada kebutuhan dunia kerjadan dunia industry; 2) Memilih materi pembelajaran sesuai dengan pokok bahasan pada pertemuan yang telah ditentukan; 3) Menetapkan kegiatan pembelajaran mata kuliah Applied Computer melalui tiga tahap kegiatan: kegaiatan awal (pendahuluan), kegiatan inti (pemberian materi, studi kasus, dan tugas-tugas yang disesuaikan pada keadaan nyata seperti di tempat kerja atau perusahaan), dan kegiatan penutup; 4) Menetapkan pendekatan dan sumber belajar seperti menentukan pendekatan masalah, metode, media, dan sumber belajar sebagai literature baik secara buku manual ataupun e-book/e-modul; dan 5) Menentukan alat evaluasi atau penilaian pembelajaran mata kuliah Applied Computer seperti menentukan bentuk aspek penilaian formatif, menentukan tugas-tugas penunjang UTS dan UAS, serta prosedur lain yang menunjang terhadap keberhasilan prestasi belajar mahasiswa sebagai salah satu tujuan pebelajaran itu sendiri.

\subsection{Pelaksanaan Pembelajaran Mata Kuliah Applied Computer dengan Model} Pembelajaran Work-Based Learning dalam Meningkatkan Prestasi Belajar Mahasiswa

Pelaksanaan pembelajaran Work-Based Learning diawali dengan: 1) Dosen memasuki ruang kelas laboratorium, menguapkan salam, mengisi daftar hadir mahasiswa secara manual dan entry data kehadiran pada system; 2) Dosen membuka kegiatan pembelajaran awal dengan mengajukan beberapa motivasi pembelajaran serta beberapa pertanyaan untuk mengulas materi pada pertemuan sebelumnya; 3) Dosen menjelaskan beberapa materi yang akan dibahas dan dipelajari pada pertemuan tersebut, sebelum memberikan materi inti; 4) Dosen memberikan materi inti sesuai dengan pokok bahasan pada pertemuan yang telah ditentukan; 5) Dosen bertindak langsung sebagai manager perusahaan dengan memberikan studi kasus dan tugastugas seperti di perusahaan; 6) Mahasiswa membuka OS Windows Microsoft Office sesuai tugas yang mereka dapatkan serta menyelesaikan berbagai tugas-tugas tersebut sesuai dengan instruksi kerja; dan 7) Dosen meminta setiap siswa untuk mengirimkan semua studi kasus dan tugas-tugas yang diberikan melalui e-mail.

4.3.Penilaian Pembelajaran Mata Kuliah Applied Computer dengan Model Pembelajaran Work-Based Learning dalam Meningkatkan Prestasi Belajar Mahasiswa

Penilaian pembelajaran harus dilaksankan guna mendapatkan tujuan pembelajaran dan capaian pembelajaran yang harus dilakukan oleh dosen setelah terlaksananya proses pembelajaran. 
Proses manajemen penilaian yang berjalan di Politeknik LP3I Bandung adalah sebagai berikut: 1) Nilai kehadiran merupakan jumlah hadir dari seluruh pertemuan. Seluruh pertemuan mata kuliah Applied Computer dalam 1 semester berjumlah 14 pertemuan dengan jumlah SKS adalah sebanyak 4 SKS; 2) Nilai formatif yang diberikan adalah berupa nilai harian saat pembelajaran sedang berlangsung, tes sumatif baik dilakukan pada awal pembelajaran, ditengah-tengah pembelajaran, atau pada akhir pembelajaran seperti quiz yang berlangung setelh pembelajaran pada pertemuan tertentu; 3) Nilai tugas merupakan nilai yang diperoleh mahasiswa yang diberikan oleh dosen baik dari tugas mandiri ataupun kelompok pada beberapa materi yang telah ditentukan; 4) Nilai UTS dapat diperoleh mahasiswa setelah mengikuti UTS dan dapat menjawab soal pertanyaan UTS secara praktik; 5) Nilai UAS dapat diperoleh mahasiswa setelah mengikuti UAS dan dapat menjawab soal pertanyaan UAS secara praktik; dan 6) Nilai akhir didapat secara kumulatif dari jumlah kehadiran, formatif, tugas, UTS, dan UAS dikali $20 \%$.

\subsection{Dampak Penggunaan Model Pembelajaran Work-Based Learning Terhadap Prestasi} Belajar Mahasiswa pada Mata Kuliah Applied Computer

Dampak yang dapat dirasakan oleh mahasiswa dari pembelajaran mata kuliah Applied Computer dengan Work-Based Learning adalah sebagai berikut: 1) Mahasiswa mendapatkan motivasi belajar dalam perkuliahan serta dapat meningkatkan kemampuan mahasiswa dalam bidang komputerisasi; 2) Kegiatan pembelajaran terjalin dengan interaksi dari berbagai arah yaitu antara dosen, mahasiswa, dan sumber belajar sehingga pembelajaran dapat berjalan dengan baik; 3) Nilai akhir yang diperoleh mahasiswa dapat meningkat; dan 4) Kompetensi yang diperoleh mahasiswa setelah mengikuti perkuliahan mata kuliah Applied Computer dengan model WorkBased Learning dapat dipertanggungjawabkan dan dapat dikembangkan dalam dunia kerja dan dunia industri.

4.5.Faktor Pendukung dan Penghambat pada Pembelajaran Applied Computer dengan Model Work-Based Learning dalam Meningkatkan Prestasi Belajar Mahasiswa Faktor pendukung pembelajaran Applied Computer dengan model Work-Based Learning guna meningkatkan prestasi belajar mahasiswa yaitu adanya team teaching atau coordinator dosen pengampu mata kuliah Aplikasi Komputer dibawah naungan prodi dapat menyusun seperangkat perencanaan pembelajaran yang menginduk pada kurikulum yang ditentukan sesuai dengan KKNI dan SKKNI serta penyesuaian dengan dunia kerja dan dunia industry (DUDI).

Faktor pendukung lainnya adalah faktor eksternal dan faktor internal. Pada faktor internal pendukung manajemen pembelajaran selain siapnya perangkat pembelajaran seperti RPS juga e-modul menjadi salah satu pendukung pelaksanaan pembelajaran, kompetensi dosen dalam penguasaan materi yang akan diberikan, profesi dosen selain mengajar juga sebagai praktisi pada beberapa perusahaan. Sedangkan pada faktor eksternal dalam pendukung pembelajaran adalah tersedianya berbagai fasilatas 
pendukung pembelajaran seperti ruang laboratorium (kelas) yang sudah dilengkapi dengan berbagai pendukung seperti, proyektor atau infokus, seperangkat komputer dosen yang menunjang pada sistem informasi akademik seperti daftar hadir, lembar kegiatan mengajar dosen, dan input nilai akademik secara online sehingga dapat memudahkan mahasiswa untuk mendapatkan informasi akademik.

Sedangkan yang menjadi factor penghambat dalam manajemn pembelajaran WorkBased Learning dalam meningkatkan prestasi belajar mahasiswa adalah keterbatasannya keadaan PC khususnya apabila laboratorium tertentu yang masih menggunakan PC komputer duduk (CPU dan Monitor) non-laptop, sehingga pembelajaran kadang-kadang terganggu dengan adanya PC yang tiba-tiba mati baik itu monitor atau CPUnya, selain itu juga apabila jumlah mahasiswa di atas 25 dan seluruhnya hadir mengikuti perkuliahan terkadang tidak mendapatkan meja komputer untuk mengikuti praktik.

Namun berbagai kendala tersebut masih dapat di atasi pada waktu berjalannya perkuliahan tersebut. Pihak kampus sudah menyiapkan staf IT yang salah satu tugasnya adalah siap dalam waktu dan kondisi apapun. Dengan demikian kendalakendala di atas dapat terselesaikan seperti menambahkan atau meminjamkan PC laptop cadangan kepada salah satu mahasiswa yang tidak mendapatkan meja komputer itu pun apabila mahasiswa tersebut tidak mempunyai atau tidak membawa laptop milik pribadi ke kampus.

\section{Kesimpulan}

Manajemen Pembelajaran mata kuliah Applied Computer dalam meningkatkan prestasi belajar siswa dengan mempergunakan model pembelajaran Work-Based Learning yang mencakup perencanaan, pelaksanaan, penilaian, dampak, serta factor pendukung dan penghambat pembelajaran Applied Computer antara lain:

1) Penentuan jadwal perkuliahan yang telah ditentukan oleh akademik sesuai dengan kalender akademik, Prodi membentuk Tim Pokja sebagai pengembang kurikulum yang terdiri dari kaprodi bersama coordinator dosen pengampu atau team teaching menyusun RPS yang merujuk pada kurikulum yang telah ditentukan, KKNI, SKKIN, serta kurikulum sertifikasi internasional dan juga mempersiapkan e-modul yang akan dipergunakan sebagai tambahan sumber belajar.

2) Pelaksanaan pembelajaran melalui model pembelajaran Work-Based Learning kegiatan pembelajaran dilakukan dengan tiga tahapan, yaitu tahap kegaiatan awal, kegiatan inti, dan kegiatan penutup. Kegaitan inti dilakukan dengan memberikan berbagai tugas dan studi kasus agar mahasiswa dapat mengetahui keadaan serta bentuk-bentuk tugas pada saat mereka bekerja di suatu perusahaan nanti, sehingga mereka dapat terbiasa mengahadapi berbagai macam bentuk pekerjaan diperusahaan tempat mereka bekerja.

3) Penilaian dilakukan melalui bentuk penilaian kehadiran, formatif, tugas/quis, UTS, dan UAS. Sedangkan bentuk instrument penilaian adalah berupa instrument untuk praktik yang dapat melengkapi materi teori yang diberikan. 
4) Nilai akhir yang diperoleh mahasiswa dapat meningkat dan kompetensi yang diperoleh mahasiswa setelah mengikuti perkuliahan mata kuliah Applied Computer dengan model Work-Based Learning dapat dipertanggungjawabkan dan dapat dikembangkan dalam dunia kerja dan dunia industri.

\section{Saran}

Work-Based learning hanya merupakan salah satu model pembelajaran yang digunakan oleh pendidikan vokasi. Model-mdel pembelajaran yang lebih bervariatif dan dapat membantu dalam kegiatan pembelajaran sangat dibutuhkan, namun pada kenyataannya tidak semua dosen dapat menggunakan model pembelajaran dengan tepat. Selain media, model pembelajaran pun menjadi salah satu penunjang tercapainya tujuan pembelajaran. Dengan demikan manajemen pembelajaran yang dimulai dari proses perencanaan, pelaksanaan, dan penilaian harus ada keterkaitan satu sama lain. SAP merupakan salah satu tahap perencanaan demi terselenggaranya pelaksanaan pembelajaran. Dengan demikian penguasaan dan pemahaman SAP diharapkan dapat membantu dosen dalam kegiatan pembelajaran.

Kondisi fisik hardware seharusnya dapat membantu setiap mahasiswa dalam kegiatan pembelajaran. PC stand alone, memang masih sangat membantu bagi beberapa mahasiswa dalam pembelajaran. Namun, penggunaan PC dengan kondisi tertentu kadang sangat menghambat dalam pembelajaran, sehingga menjadi salah satu penyebab terganggunya pembelajaran secara kondusif. Dengan demikian PC dengan upgrade versi OS terbaru serta penggunaan Office versi terbaru pun sangat dibutuhkan dan akan membantu terselenggaranya pembelajaran yang kondusif.

\section{Daftar Pustaka}

[1] Benny A. Pribadi. 2009. Model desain Sistem Pembelajaran. Jakarta: Dian Rakyat

[2] Boud, D., \& Solomon, N. (2001). Work-based learning a new higher education. London: SRHE and Open University Press.Hamid, D. 2011. Metode Penelitian Pendidikan. Bandung: Alfabeta

[3] Creswell, W. John. 2013. Research Design: Pendekatan Kualitatif, Kuantitatif, dan Mixed.

[4] Fachruddin, A. 2016. Manajemen Pertelevisian Modern. Yogyakarta: Penerbit Andi \& Universitas Mecu Buana

[5] Garina, P. R. 2015. Manajemen Pembelajaran Bahasa Arab di Sekolah Tinggi Agama Islam Sunan Pandanaran Yogyakarta. Yogyakarta: Tesis Pascasarjana UIN Sunan Kalijaga

[6] Habsari, S. 2005. Bimbingan dan Konseling SMA. Jakarta: Grasindo

[7] Hamalik, O. 2006. Manajemen Pengembangan kurikulum. Bandung: Remaja Rosadakarya

[8] Herujito, Yayat M. 2001. Dasar-dasar Manajemen. Jakarata: Grasindo Jakarta.

[9] Hoesada Jan. 2013. Taksonomi Ilmu Manajemen. Yogyakarta: Andi 
[10] Medhat, S. (2008). The path to productivity : The progress of Work-Based Learning strategies in higher education engineering programmes. Final Report. London : The New Engineering Foundation

[11] Mujiati. Irawan, B. dan Raharjo, S. 2013. Pengembangan Modul Bercirikan WorkBased Learning untuk Meningkatkan Prestasi Siswa SMK Pada Materi Matematika Keuangan. Jurnal KNPM Vol-V Juni 2013, Himpunan Matematika Indonesia Universitas Negeri Malang.

[12] Olivia, F. 2011. Tools For Study Skill, Teknik Ujian Efektif. Jakarta: PT Elex Media Komputindo.

[13] Siswanto, T.B. 2011. Pendidikan Vokasi, Work-Based Learning, dan Penyelenggaraan Program Praktik Pengalaman Lapangan. UMM Magelang: tidak diterbitkan Yogyakarta: Pustaka Pelajar.

[14] Sumarsan, T. 2013. Sistem Pengendalian Manajemen: Konsep, Aplikasi, dan Pengukuran Kinerja. Jakarta: PT.Indeks

[15] Syarifuddin. 2005. Manajemen Pembelajaran. Medan: Quanyatum Teaching

[16] Wena, M. 2011. Strategi Pembelajaran Inovatif Kontemporer. Jakarta: Bandung

[17] Widarto. Model Pendidikan Vokasi yang Efektiv dan Efisien. (Online). Tersedia: http://staff.uny.ac.id/, diakses pada 20 Agustus 2016.

[18] Winardi, J. 2004. Manajemen Perilaku Organisasi. Jakarta: Kencana. 